\title{
Efficacy of Acute Normovolemic Hemodilution in the Setting of Chronic Anemia
}

Andrew Vieira

University of South Florida

\author{
Advisors: \\ Arcadii Grinshpan, Mathematics and Statistics \\ Julio Arrieta, Emergency Medicine, Sarasota Memorial Hospital \\ Problem Suggested By: Julio Arrieta
}

Follow this and additional works at: https://digitalcommons.usf.edu/ujmm

Part of the Mathematics Commons

UJMM is an open access journal, free to authors and readers, and relies on your support:

Donate Now

\section{Recommended Citation}

Vieira, Andrew (2017) "Efficacy of Acute Normovolemic Hemodilution in the Setting of Chronic Anemia," Undergraduate Journal of Mathematical Modeling: One + Two: Vol. 7: Iss. 2, Article 3.

DOI: http://doi.org/10.5038/2326-3652.7.2.4878

Available at: https://digitalcommons.usf.edu/ujmm/vol7/iss $2 / 3$ 


\title{
Efficacy of Acute Normovolemic Hemodilution in the Setting of Chronic Anemia
}

\begin{abstract}
A theoretical model for calculating hematocrit as it relates to blood volume loss was used to test the theoretical impact of acute normovolemic hemodilution prior to surgery in a chronically anemic patient. The technique of hemodilution is intended to decrease red blood cell loss that occurs as the result of surgical intervention, however its impact may be decreased in an anemic patient. An equation to find change in hematocrit resulting from blood volume loss was elucidated via integration. This equation was then applied to a theoretical patient with $5 \mathrm{~L}$ of blood and a hematocrit of 32 percent which revealed a net decrease in red blood cell loss of $90 \mathrm{~mL}$ with the use of hemodilution as compared to without. Such a small decrease in net red blood cell loss may not be sufficient benefit for the financial and time costs that such a procedure would cost.
\end{abstract}

\section{Keywords}

hematology, anemia, normovolemic hemodilution, hematocrit

Creative Commons License

(c) (i) (3)

This work is licensed under a Creative Commons Attribution-Noncommercial-Share Alike 4.0 License. 


\section{PROBLEM STATEMENT}

Analyze the efficacy of acute normovolemic hemodilution to conserve blood in a chronically anemic patient.

\section{Motivation}

Any form of surgical intervention carries dangers and risks which medical professionals are constantly attempting to minimize. A particular risk of surgery is blood loss that can occur and the subsequent need for blood transfusions. Clearly blood loss that occurs during surgery can be detrimental; however the use of blood from donors can also carry many risks such as the transfer of illness or unexpected reactions to the foreign blood. In this same vein, certain religious beliefs prevent individuals from being able to receive blood transfusions making surgery an even greater risk to them.

The main concern of blood loss during surgery is a loss of red blood cells leading to ischemic injury to tissues due to a lack of oxygen supply. Volume depletion leading to hypotension is not as great a concern because the liquid blood can be replaced with saline fluids; however saline fluids are obviously not capable of supplying the necessary oxygen to the body. A technique used to prevent red blood cell loss over time during a surgery is acute normovolemic hemodilution. This involves removing some of the blood prior to surgery and replacing it with saline ahead of time. Therefore, the concentration of red blood cells in the blood, known as the hematocrit, will be lower and in turn the amount of red blood cells lost per unit volume of blood will be decreased. This in theory should decrease the overall amount of red blood cells lost once the pre-removed blood is returned to the patient and can reduce the need for exogenous blood transfusions after surgery. A simple mathematical equation has been created to model the effects 
of such technique (Brecker and Rosenfeld, 1994). This research aims to apply this model in the setting of a patient with a chronically low hematocrit to see if such a procedure is still feasible. For the purposes of this research the theoretical anemic patient will have a hematocrit of 32 percent and will be assumed to have an average blood volume of 5 liters.

\section{MATHEMATICAL DESCRIPTION AND SOLUTION APPROACH}

A model by Bourke and Smith (1975) relates the rate of change of Hct (hematocrit) per $V_{L}$ (volume loss) to the total hematocrit and EBV (estimated blood volume).

$$
\frac{d H c t}{d V_{L}}=\frac{-H c t}{E B V}
$$

When integrated (1) from an initial hematocrit to a presumed final hematocrit following surgery formula relating initial and final hematocrits can be obtained as demonstrated below.

1. The reciprocal of both sides of the equation (1) was taken and the integral was made:

$$
\int \frac{d V_{L}}{d H c t}=-E B V \int_{H c t_{0}}^{H c t_{F}} \frac{1}{H c t}
$$

2. The equation (2) was integrated in terms of volume loss:

$$
\left.V_{L}=-E B V \ln (H c t)\right]_{H c t_{0}}^{H c t_{F}}
$$

3. The resulting equation of the definite integral (3) was found and the natural logs were simplified:

$$
V_{L}=-E B V \ln H c t_{F} / H c t_{0}
$$

4. -EBV was divided to the other side (4) and the anti-log was taken of both sides:

$$
e^{\left(\frac{-V_{L}}{E B V}\right)}=H c t_{F} / H c t_{0}
$$


5. The equation (5) was simplified to equal final hematocrit and from this a simple exponential decay equation is found:

$$
H c t_{F}=H c t_{0} e^{\left(\frac{-V_{L}}{E B V}\right)}
$$

Now the proposed scenario is that of an anemic patient (hematocrit of 32 percent) who undergoes a surgery that results in a 1.5 liter loss of blood volume which in turn represents a 480 mL loss of red blood cells (RBCs). Applying this model and (6) for a situation in which hemodilution is not done would result in a final hematocrit of 24 percent as demonstrated below:

$$
H c t_{F}=0.32 e^{\left(\frac{-1.5}{5}\right)}=0.24
$$

Now, for this model, let us assume hemodilution in which 1 liter of blood (equaling $320 \mathrm{~mL}$ of $\mathrm{RBCs}$ ) is drawn prior to surgery and replaced with fluids is performed. The resulting initial hematocrit would be 26 percent:

$$
\operatorname{Hct}_{F}=0.32 e^{\left(\frac{-1}{5}\right)}=0.26
$$

The same surgery is performed and once again 1.5 liters of the now diluted blood is lost during the procedure. The resulting hematocrit immediately post-surgery would be 21 percent and the RBC loss would be $390 \mathrm{~mL}$ :

$$
H c t_{F}=0.26 e^{\left(\frac{-1.5}{5}\right)}=0.21
$$

The pre-surgical blood drawn for hemodilution would be reintroduced. So the total loss of RBCs when hemodilution is not performed would be $480 \mathrm{~mL}$ when compared to $390 \mathrm{~mL}$ when it is performed in this anemic patient. This results in a net saving of $90 \mathrm{~mL}$ of RBCs. 


\section{DISCUSSION}

The aim of hemodilution prior to surgical intervention is to reduce total red blood cell loss and decrease the need for blood transfusions following surgery. However, if the benefit of hemodilution is very small, it may not be worth the cost or risk that could be associated with it. In the context of an already anemic patient it may not be worth the risk of depleting the already smaller red blood cell count such patients have. In the case of this proposed model, the hypothetical patient only saved a net amount of $90 \mathrm{~mL}$ worth of red blood cells. This is a very small amount in the larger context of the $400-500 \mathrm{~mL}$ of red blood cells that would be lost in the surgery. Also, since the initial hematocrit is already lower than in an average healthy patient therefore the removed blood is less concentrated so clearly reintroducing less concentrated blood post-surgically is not ideal. Therefore, overall acute normovolemic hemodilution may not be appropriate for chronically anemic patients.

The conclusions of this study rely on many assumptions and also on a simplistic model of hematocrit in relationship to blood volume and blood loss. Data comparing the model to the results of hemodilution that has been performed prior to surgeries of real patients, whether they are healthy or anemic are used. Furthermore, the situation proposed in this paper assumes a set blood loss count and does not take into account the possibility of larger amounts of blood loss or for varying amounts of initial blood volume of patients. 
Nomenclature

\begin{tabular}{ccc}
\hline Symbol & Description & Value \\
\hline \hline $\mathrm{L}$ & Unit for measuring volume & Liter \\
$\mathrm{mL}$ & $1 / 1,000 \mathrm{~L}$ & Milliliter \\
& & \\
$\mathrm{V} \mathrm{L}$ & Volume loss & $\mathrm{L}, \mathrm{mL}$ \\
$\mathrm{EBV}$ & Estimated Blood Volume & $\mathrm{L}, \mathrm{mL}$ \\
$\mathrm{H}$ & $\begin{array}{l}\text { Hematocrit: the ratio of the volume of red blood } \\
\text { cells to the total volume of blood }\end{array}$ & $\%$ \\
\hline
\end{tabular}

\section{REFERENCES}

Bourke, D. L., and Smith, T. 1974. Estimating allowable hemodilution. Anesthesiology, 41, pp. 609-612.

Brecher, M. E., and Rosenfeld, M. 1994. Mathematical and computer modeling of acute normovolemic hemodilution. Transfusion, 34, pp. 176-179

Day, T., and Stewart, J. 2016. Biocalculus: Calculus, Probability, and Statistics for the Life Sciences. Cengage Learning. 